Transportation Research Forum

Effects of Light and Commuter Rail Transit on Land Prices: Experiences in San Diego County Author(s): Robert Cervero

Source: Journal of the Transportation Research Forum, Vol. 43, No. 1 (Spring 2004), pp. 121-138

Published by: Transportation Research Forum

Stable URL: http://www.trforum.org/journal

The Transportation Research Forum, founded in 1958, is an independent, nonprofit organization of transportation professionals who conduct, use, and benefit from research. Its purpose is to provide an impartial meeting ground for carriers, shippers, government officials, consultants, university researchers, suppliers, and others seeking exchange of information and ideas related to both passenger and freight transportation. More information on the Transportation Research Forum can be found on the Web at www.trforum.org. 


\section{Effects of Light and Commuter Rail Transit on Land Prices: Experiences in San Diego County}

Using hedonic price models, appreciable land-value premiums were found for multiple land uses in different rail corridors of San Diego County. The most appreciable benefits were for condominiums and single-family housing near commuter-rail stations in the north county, multifamily housing near light-rail stations, and commercial properties near downtown commuterrail stations and light-rail stops in the Mission Valley. Elsewhere, commercial properties accrued small or even negative capitalization benefits. Pro-development policies, worsening traffic congestion, and a generally healthy economy are thought to have generally boosted land values in San Diego County, though impacts are corridor- and land-use specific.

\section{by Robert Cervero}

Real-estate prices reveal the degree to which rail-transit investments confer benefits, if any. As long as there are finite supplies of land near rail stations, theory holds, those wanting to live, work, or do business near transit will bid up land prices. The benefits of having good connectivity to the rest of the region i.e., being accessible - get capitalized into the market value of land.

This paper explores the degree to which this proposition holds for two forms of highcapacity transit - light and commuter rail across residential and non-residential properties in the San Diego region. Relatively little is known about the land-value impacts of commuter rail transit even though far more track miles of commuter rail transit have been laid in the United States than light- and heavyrail systems put together (American Public Transportation Association, 2002).

From a policy standpoint, it is important to understand land-market impacts of transit for several reasons: (1) to measure benefits, to the degree they exist, in part to help mediate disputes about impacts of proposed extensions or service improvements; (2) to provide evidence that can be used in crafting financial arrangements as part of public-private joint development deals; and (3) to help in designing possible new forms of creative infrastructure financing, such as benefit assessments, betterment charges, or other forms of value capture.

The San Diego region provides a favorable setting for examining transit and land-use relationships because it has long been at the forefront of promoting transit-oriented development (TOD) (Calthorpe, 1993; Bernick and Cervero, 1997; Boarnet and Crane, 2001). In contrast to the regulatory approach of Portland, Ore., to land-use management, the San Diego area has opted for carrots over sticks, using various incentives to entice private investments near rail stops. The region's planning entity, the San Diego Association of Governments (SANDAG), has adopted a land-use distribution element that directs growth to "transit-focused areas" along existing and planned high-capacity rail lines. The City of San Diego was the first U.S. municipality to formally adopt a TOD ordinance that encourages compact, infill development near light-rail stops. Urban village overlay zones have also been used to increase densities and inter-mix land uses near stations. To help San Diego prepare for one million new residents over the next 20 years, many policy-makers today openly embrace TOD as a preferred model of urbanization.

This paper is divided into several sections. First, past work on land-value impacts of transit are reviewed, including 
experiences in San Diego County. Second, the methodology and data sources used in the research are discussed. Third, descriptive statistics and research results are presented. Last, findings and their policy implications are summarized.

\section{TRANSIT AND LAND-VALUE IMPACTS}

Below, past research on land-value impacts are reviewed for residential and commercial land uses. Evidence is far from crystal clear. While different findings are attributable, in part, to local contextual factors (e.g., station designs, softness of local real-estate markets) and timing (e.g., whether the market was on an upswing or downswing), they also reflect differences in methodologies (e.g., simple matched pairs, repeat sales ratios, and hedonic price models) and measurements (see Cervero, 1997 for further discussions).

\section{Residential Properties}

Most, though not all, hedonic-price studies of transit's impacts on residential properties have recorded premiums. The largest have come from heavy and commuter-rail systems operating in big metropolitan areas. A San Francisco Bay Area study found that for every meter a single-family home was closer to a BART station in 1990, its sales price increased by $\$ 2.29$, all else being equal (Landis et al., 1994). A 1993 study of residential properties near the 14.5-mile Lindenwold Line in Philadelphia, using hedonic price models, concluded that access to rail created an average housing value premium of $6.4 \%$ (Voith, 1993). In contrast, a hedonic-price study of residential properties near the Miami Metrorail system concluded that proximity to rail stations induced little or no increase in housing values (Gatzlaff and Smith, 1993). This could reflect Miami Metrorail's fairly modest service coverage (21 one-way track miles) in comparison to systems like the 95mile BART. Yet experiences with the 41-mile MARTA system in Atlanta have also been inconclusive: one study found that transit accessibility increased home prices in Atlanta's lower-income census tracts but decreased values in upper-income areas (Nelson, 1992).

Conflicting results are even evident among studies that focused on impacts for residential parcels very near (e.g., adjacent or a few blocks away) versus farther (e.g., beyond audible distance) from a rail station. A study of Portland's MAX light-rail system found positive land-value effects only within a 500meter walking distance of stations (AlMoisand, et al., 1993). In contrast, Workman and Broad's 1997 study of light-rail-served Portland and heavy-rail-served Oakland suburbs found residential property values were lower within a few blocks of rail stops than five or six blocks away. Yet another study found no disamenity effect for single-family homes within 300 meters of BART stations (Landis et al., 1994). The same study, however, recorded a huge effect for commuterrail services: in 1990, homes within 300 meters of CalTrain stations sold at an average discount of $\$ 51,000$. And in the case of San Jose's light-rail system, the same study found single-family homes within 300 meters of stations were worth around $\$ 31,000$ less than equivalent properties beyond transit's immediate impact zone, controlling for other factors. It seems plausible that whereas disamenity effects exist from being "too close" to rail transit in suburban settings, in fairly dense, mixed-use environments, ambient noise levels are so high and streets are so busy that any perceived nuisances from living within a block or so of a stop are muted. The alignment also comes into play: because of noise levels, elevated structures generally depress residential values whereas the effects of below-ground systems are often negligible. Nelson (1992) found this to be especially so in higher income neighborhoods served by Atlanta's aerial rail lines. On the other hand, Lin (2002) found residential properties adjacent to Chicago's elevated structures increased 20\% more in value between 1985 and 1991 than those located a half-mile away. Local factors, such as the quality of rail services (which are very high in Chicago) and 
availability of station-area parking (generally plentiful in Atlanta but restricted in Chicago) could explain such variations.

\section{Transit and Commercial Properties}

Most evidence on commercial properties comes from heavy rail systems, and as in the case of residential properties, it is inconsistent. An early study of BART, using repeat-sales data, found no evidence that rail's presence increased commercial property values around a suburban station and two inner-city stops over the long term (Falcke, 1978). Two hedonic-price studies of Atlanta's MARTA system reached opposite conclusions on impacts to commercial properties. One found offices within a mile of freeway interchanges commanded rent premiums, however those within a mile of MARTA stations typically leased for less than comparable space farther away (Bollinger et al., 1998). In contrast, Nelson (1999) found commercial properties were "influenced positively by both access to rail stations and policies that encourage more intensive development around those stations." Nelson's findings suggest that the combination of targeting commercial development and forming special districts that relax parking and density requirements produce synergies.

Whether adjacent commercial properties are physically integrated with rail stations, such as through air-rights development or direct passageway connections, appears to have a bearing on market performance. A study of five rail stations in Washington, D.C. and Atlanta over the 1978-89 period found jointly developed projects were better performers: in addition to average rent premiums of $7 \%$ to $9 \%$, physically integrated projects tended to enjoy lower vacancy rates and faster absorption of new leasable space (Cervero, 1994). Joint development projects, the study found, were generally "better" projects - i.e., they were architecturally integrated, enjoyed better on-site circulation (of both people and cars), and made more efficient use of space through resource-sharing (e.g., shared parking). Another study of older neighborhoods and business districts in the Northeast found rail-station rehabilitation had a positive effect on surrounding property values and tax revenues, with benefits increasing with city size and urban densities (Great American Station Foundation, 2001).

Although theory suggests light-rail systems confer smaller benefits to commercial properties than do heavy-rail investments, some researchers have reported otherwise. A study of the Dallas Area Rapid Transit (DART) light-rail system compared differences in land values of matched pairs of comparable retail and office properties - some near DART and others not (Weinstein and Clower, 1999). Between 1994 and 1998, the average value of retail and office properties near DART stops increased by 37\% and 14\%, respectively; for control parcels, the averages were $7.1 \%$ and $3.7 \%$.

Several recent studies of light-rail's impacts on commercial properties in California adopted more rigorous research designs, however findings varied. One study was unable to assign benefits because of confounding influences - commercial projects closer to rail stops tended to be better quality projects and thus leased for more (Landis and Loutzenheiser, 1995). A study of Santa Clara County's light-rail system found that properties within a half-mile of stations commanded rent premiums, and those that were a quarter to a half-mile away were worth even more (Weinberger, 2001). Compared to other properties in the County, the estimated monthly lease premium within one-quarter mile of a station was 3.3 cents per square foot and for properties one-quarter to one-half mile away, it was 6.4 cents per square foot.

Insights into the effects of commuter rail services on commercial properties are fairly sketchy. A recent hedonic-price study found value premiums that exceeded $100 \%$ for commercial parcels near commuter-rail stops in healthy business districts of Santa Clara County, but not elsewhere (Cervero and Duncan, 2002). Benefits were recorded for one of the County's commuter-rail systems (CalTrain that connects San Jose and San Francisco), but not the other (Altamont Commuter Express, or ACE, that links the Silicon Valley to pockets of affordable housing in the Central Valley). 


\section{TRANSIT IN SAN DIEGO}

San Diego County, through the leadership of the Metropolitan Transit Development Board (MTDB), has aggressively pursued rail development over the past 15 years. With an average annual population growth rate of $1.2 \%$ during the 1990s (reaching 2.84 million inhabitants in 2000) and America's fifth most congested freeways in 2000 according to the Texas Transportation Institute (2002), local officials have turned to rail in hopes of stemming future traffic congestion and promoting sustainable growth. In 1981, San Diego introduced America's first recentgeneration light rail services with the opening of the South Line from downtown to the Mexican border (Figure 1). A decade later, the South Line was augmented by the 17.3mile East Line to El Cajon which in 1997 was extended an additional 3.6 miles to Santee. The most recent line, Mission Valley, opened in late 1997, a year after the extension from downtown San Diego to Old Town along an

Figure 1: Regional Rail Transit Network and Planned Extensions in San Diego, 2000

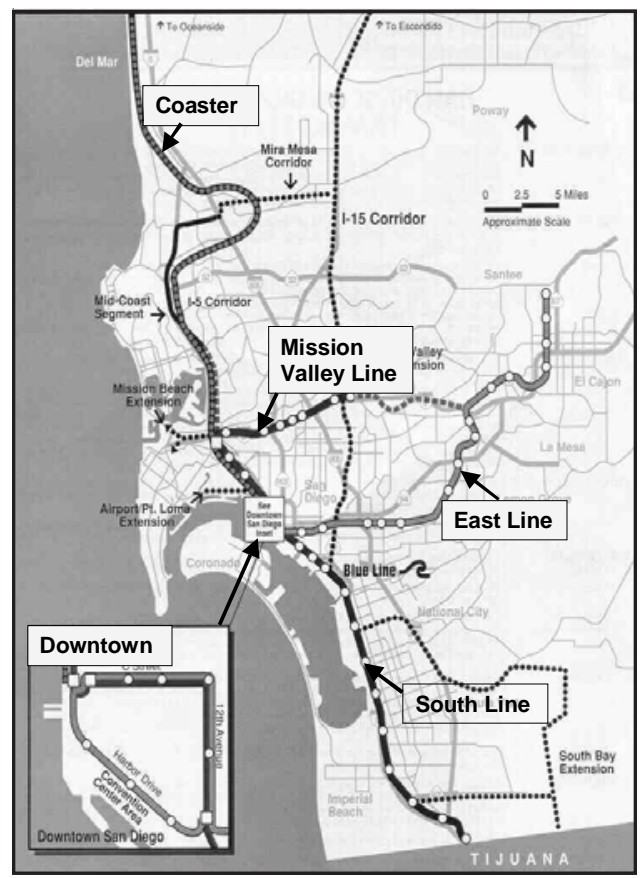

Source: Metropolitan Transit Development Board, San Diego, 2000. existing rail line. The Mission Valley line was celebrated as a departure from past practices, with considerable emphasis given to promoting TOD rather than minimizing investment costs. Today, 47 one-way track miles of light rail "Trolley" services are in place, and an equal amount is slated for construction over the next two decades. A commuter rail service, called the Coaster, opened in 1996, operating between Oceanside (in the wealthy northern part of the county) and downtown San Diego, a distance of 43 miles.

The first notable study on the impact of San Diego Trolley services was a 1984 report, "San Diego Trolley: The First Three Years," prepared by SANDAG. Although no effort was made to quantify impacts, interviews with developers and merchants revealed many felt being near Trolley stops was advantageous. Most developers indicated that being near a Trolley station was a "major part of their marketing efforts in leasing space." Around $20 \%$ of merchants stated that the Trolley was an "important positive factor in the business remaining in its current location.” However, nearly $40 \%$ of respondents indicated that the Trolley had no impact, positive or negative, on sales volumes. These surveys were administered when the Trolley service had been in operation for just a few years and only linked downtown and the Mexican border. Often, it takes a while for the benefits of being near transit to accrue, thus it was perhaps presumptuous to have expected a chorus of support among developers and businesses at the time of the surveys.

A study that examined impacts a decade following the Trolley's opening, relying mainly on qualitative case assessments, concluded relatively little suburban development could be associated with the presence of light-rail stations, though proactive government involvement was credited with clustering commercial and office development near some downtown stops (Graham, 1992). The study concluded most stations were located in settings unsuitable for TOD. 
Land Prices

The first study that placed a monetary figure on the value to commercial properties of being near Trolley stops was by VNI Rainbow (1992). This analysis examined rents as opposed to land values and used the technique of matched pairs - i.e., simple comparisons of differences in rents among properties that were comparable except some were near rail stops and others were not. Gauging benefits using rental data can be problematic because contract rents do not always reflect concessions received by tenants. Based on projects built three or more years after the Trolley's 1981 opening, no measurable differences in monthly rents were found for offices adjacent to downtown Trolley stops versus offices of similar quality but in the suburbs. Because suburban offices are so fundamentally different than those downtown, the validity of such matched-pair comparisons is questionable. In the case of retail businesses, fairly significant benefits were recorded, around \$1.35 per square foot (in 1980 dollars). In fact, monthly rents for retail establishments adjacent to Trolley stations were, on average, $167 \%$ higher than control properties that were one-half block away. Other confounding factors, like pedestrian levels, could have explained such sharp differences.

A more rigorous study of San Diego's experiences was conducted by Landis et al (1994). Using data for 134 single-family home sales in the city of San Diego in 1990 and a hedonic price structure, the study found Trolley services conferred appreciable landvalue benefits (in contrast to negative impacts found for other light rail systems in California). The authors found the typical single-family home price increased by $\$ 2.72$ for every meter it was closer to a Trolley station. Outside the city limits, relationships were insignificant, suggesting that while the accessibility premium associated with the San Diego Trolley is quite high, it is limited in extent to homes in the city of San Diego. Because this study investigated relationships during a period of economic downturn and prior to pro-TOD policies, its relevance to the political and economic climate of today is questionable.

\section{DATA AND METHODOLOGY}

Given the inconsistencies of past research and the fact that the San Diego area has aggressively pursued TOD since the work of Landis et al. (1994), the work presented below refines and extends our understanding of transit's land-value benefits. Also, the opening of commuter rail services adds a new wrinkle to the study of capitalization impacts in San Diego County. Data sources and methodologies used in this present study are discussed below.

\section{Data Sources}

Data on property sales came from Metroscan, a proprietary data base available from First American Real Estate Solutions. Metroscan contains monthly information on all real estate sales transactions recorded by county assessors. To produce a large enough sample, data on commercial properties were extracted for 1999, 2000, and 2001; for residential parcels, sufficient numbers of cases for year 2000 were available and used for the analysis.

Since capitalization effects are thought to vary across land uses, separate models were estimated for single- and multi-family housing, condominiums, and commercial properties. Metroscan records were only selected for parcels that sold in the year of analysis: 2000 for residential and 1999-2001 for commercial properties. Moreover, records were only selected if the sales price and assessed value of land and structures were within 10 percent of each other, removing suspicious cases with extremely high or low sale values (including possibly those that did not involve arms-length transactions). This yielded the following numbers of records:

- Multi-family housing: 1,495 parcel records

- Condominiums: 9,672 parcel records

- Single-family housing: 14,756 parcel records

- Commercial: 372 parcel records.

For commercial properties, the following land uses (and shares of the sample) in the database were: 
- General Offices and Others, 1-3 story buildings (65.6\%)

- Restaurant (6.4\%)

- Offices-Medical (6.4\%)

- Hotel-Motel (4.7\%)

- Vacant (4.2\%)

- Office Condominiums (3.4\%)

- Bank-Finance (2.4\%)

- Neighborhood Shopping Center (2.3\%)

- Community Shopping Center (1.7\%)

- Offices and Others, 4 story buildings and higher (1.2\%)

- Grocery-Drug Store (1.1\%)

- Other (0.4\%)

In addition to price information, Metroscan provided other parcel data like structure size, year built, and address information. Address data allowed the longitudinal-latitudinal coordinates of parcels to be identified. Other key data, including tract-level information on employment, income, and zone-to-zone travel times, came from SANDAG and the year 2000 U.S. Census (Summary Tape File 3A).

\section{Hedonic Price Modeling}

To gauge the capitalization benefits, hedonic price models were estimated. Hedonic price theory assumes that most consumer goods comprise a bundle of attributes and that the transaction price can be decomposed into the component (or 'hedonic') prices of each attribute (Rosen, 1974). Hedonic models of the following form were estimated: $\mathrm{P}_{\mathrm{i}}=f(\mathrm{~T}$, A, S, C), where: $P_{i}$ equals the estimated price of parcel $\mathrm{i}$; $\mathrm{T}$ is a vector of transportation proximity to transit and highways, and accessibility via highway and transit networks; A is a vector of property characteristics (e.g., structure size and age) and location attributes (e.g., type of commercial); $\mathrm{S}$ is a vector of neighborhood socio-demographic characteristics (e.g., racial composition, household income); and $\mathrm{C}$ is a vector of fixed-effects controls. Table 1 lists the variables for each of the vectors that were considered as candidates for entry into the hedonic price models along with their data sources. The signs of model coefficients, revealing how each variable is expected to influence land prices, is also shown in the table. The challenge in measuring transit's value-added is to partial out the influence of proximity to transit stops vis-à-vis all of the other factors that increase property values. The hedonic structure allowed for the influences of various factors (e.g., size of structure; quality of neighborhood) to be statistically controlled so the influences of proximity to rail could be isolated. Classic bid-rent theory (see Alonso, 1964) holds, for example, that residential property values rise with relative proximity to workplaces, thus a variable like regional job accessibility over highway and transit networks is important to include in order to control for this effect - i.e., the relative accessibility of a parcel to employment opportunities. Fixed-effect (dummy) variables, like the municipality in which a property lies, statistically captured the unique attributes of communities, such as quality of schools.

Many of the predictor variables related to location, proximity to transit, neighborhood attributes, and accessibility were measured using Geographic Information System (GIS) tools. One-quarter and one-half mile buffers were created around all rail transit stops in the county as well as all freeway and gradeseparated interchanges. The $1 / 4$ to $1 / 2$ mile range is considered to be an acceptable walking distance to rail stops in U.S. cities (Calthorpe, 1993; Bernick and Cervero, 1997). The distance ring (either $1 / 4$ or $1 / 2$ mile) that provided the best statistical fits in predicting sales prices were used in the analyses. For purposes of gauging neighborhood attributes (such as neighborhood median household income and racial composition), one-mile buffers around parcels were digitally overlaid on to census blocks. Neighborhood attributes, therefore, were expressed for a consistent geographic area (around 2,010 acres). Buffers were also created to identify parcels lying within one and five miles of the Mexican border to account for possible boundary effects.

A key predictor variable of the hedonic price models was accessibility. For residential properties, isochronic measures of accessibility gauged the number of jobs within 
Table 1: Vector Variables, Expected Signs, and Data Sources

\begin{tabular}{|c|c|c|c|}
\hline Vector & Variables & $\begin{array}{l}\text { Expected } \\
\text { Signs }\end{array}$ & Data Sources \\
\hline \multirow[t]{3}{*}{$\begin{array}{l}\text { T: Transportation } \\
\text { Proximity }\end{array}$} & $\begin{array}{l}\text { Proximity to light or commuter rail } \\
\text { station }\end{array}$ & + & Census Tiger Files; SANDAG GIS files \\
\hline & Interchange ramp proximity & $+^{\mathrm{a}}$ & Census Tiger Files; SANDAG GIS files \\
\hline & Highway distance & - & Census Tiger Files; SANDAG GIS files \\
\hline \multirow{7}{*}{$\begin{array}{l}\text { A: Property } \\
\text { and Location } \\
\text { Attributes }\end{array}$} & $\begin{array}{l}\text { Regional job accessibilility (highways } \\
\text { and transit) }\end{array}$ & + & $\begin{array}{l}\text { SANDAG employment and travel-time } \\
\text { data; Census Tiger files }\end{array}$ \\
\hline & $\begin{array}{l}\text { Regional household accessibility } \\
\text { (highways and transit) }\end{array}$ & + & $\begin{array}{l}\text { SANDAG employment and travel-time } \\
\text { data; Census Tiger files }\end{array}$ \\
\hline & Structure size & + & Metroscan \\
\hline & Lot size & + & Metroscan \\
\hline & Structure age & - & Metroscan \\
\hline & Number of bedrooms, bathrooms & $+t^{\mathrm{b}}$ & Metroscan \\
\hline & Type of commercial use & $?^{\mathrm{c}}$ & Metroscan \\
\hline \multirow{3}{*}{$\begin{array}{l}\text { S: Neighborhood } \\
\text { Socio- } \\
\text { Demographic } \\
\text { Characteristics }\end{array}$} & $\begin{array}{l}\text { Neighborhood demographic } \\
\text { characteris ics (household income, } \\
\text { age structure, race) }\end{array}$ & $?^{d}$ & 2000 Census STP-3A; Census Tiger Files \\
\hline & Vacant land in neighborhood & $?^{\mathrm{e}}$ & 2000 Census STP-3A; Census Tiger Files \\
\hline & Proximity to Mexican border (0-1) & $?^{\dagger}$ & 2000 Census STP-3A; Census Tiger Files \\
\hline \multirow[t]{2}{*}{ C: Fixed Effects } & City Code (0-1) & $?^{g}$ & Metroscan \\
\hline & Month Code (0-1) & $?^{\mathrm{n}}$ & Metroscan \\
\hline
\end{tabular}

\section{Codes}

$+\quad=$ Positive effect

$--\quad$ = Negative effect

$?=$ Uncertain or varied effect

$\mathrm{a}=$ Proximity to highway interchange is likely most valued by commercial properties.

b = Absolute property values generally increase with numbers of bedrooms and bathrooms, however controlling for structure size, the relationship is often the inverse indicating housing with fewer but larger bedrooms are preferred to those with more but smaller bedrooms.

$c=$ Capitalization benefits likely vary among types of commercial uses (e.g., shopping centers, restaurants) depending upon local real-estate market conditions.

$d=$ Demographic variables generally influence land values differently depending upon types of residential properties. Single-family housing values generally rise with neighborhood income however this is not necessarily the case for rental apartment projects. An older age structure sometimes signifies a more stable neighborhood, thus increasing single-family home prices, however for apartment markets that cater to younger households, a younger age structure might more strongly influence land values. Influences of the racial composition of households are less clear, particularly once income is controlled for, however the price of single-family residential parcels are generally thought to be higher in more homogenous, predominantly white neighborhoods.

e = Capitalizaiton effects likely vary according to local real-estate market conditions. In healthy markets, vacant land is often an asset since it can easily be built upon whereas in stagnant markets, vacant land often signifies disinvestments and sometimes abandonment.

$f=$ Capitalization effects likely vary by land use. Commercial properties most likely benefit from being close to an active border crossing whereas residential properties most likely experience a nuisance effect.

$\mathrm{g}=$ Varies by city. Residential parcels in communities with high-rated school systems generally reap a land-value benefit.

$\mathrm{h}=$ Varies by month or year. During periods of economic growth, land values are generally higher and when there is an economic downturn, they generally fall. 
designated travel-time intervals of 15 minutes, 30 minutes, 45 minutes, and one-hour over highway and transit networks. An isochronic measure provides a cumulative count of activities, like number of jobs, within a defined amount of travel time (Koenig, 1980). For commercial properties, accessibility to households (as indicators of relative proximity to consumers and workers) was measured. Accessibility analyses were conducted at the traffic analysis zone (TAZ) level using year2000 travel-time estimates provided by SANDAG. TAZs are geographical areas, often similar in size to census tracts, which are used for modeling and forecasting travel demand in metropolitan areas. Thus, indices gauged levels of accessibility for the centroid of a TAZ that a particular parcel lies within.

The hedonic price models were specified to allow capitalization effects to be measured by a parcel's land use (e.g., multi-family residential, commercial), type of rail operations (e.g., light or commuter rail), and in the case of light-rail services, the corridor in which the parcel lies (e.g., South Line or Mission Valley Line). Price effects are thought to vary among land uses because the implicit value assigned to transit accessibility likely differs depending upon local real estate market conditions, a neighborhood's sociodemographic profiles, and other factors. Theory holds, for example, that in tight real estate markets, commercial land uses can generally outbid others for highly accessible locations like transit station areas because of the potential for greater profits (or utilities). Accordingly, one might expect transit's valueadded to be highest for commercial land uses. This might be particularly the case given that 1999-2001 was a period of buoyant economic growth and rising real estate prices in the San Diego region. Additionally, since households residing in multi-family units have lower average incomes than those living in owneroccupied units and also tend to be more transitdependent, one might similarly expect landvalue premiums to be significant for apartments and other rental units, especially in lower income settings.
The models presented in this article also allow the influences of transit technologies to be probed. As an exclusive right-of-way operation that provides high-speed peakperiod services, commuter rail lines might be expected to confer greater land-value benefits than light-rail services that operate, some of the time, in mixed-traffic conditions at slower speeds (like San Diego’s Trolley). However, the accessibility advantages, and thus landvalue premiums, of commuter rail might only hold for owner-occupied residential units since these services cater to professional-class workers with downtown office jobs. Suburban businesses that depend upon good access all hours of the day and days of the week might reap negligible accessibility benefits from a predominantly peak-hour, work-trip-oriented commuter rail service. Lastly, the relative strength or softness of real estate markets, and thus capitalization effects, likely vary by corridors and sub-regions according to local supply-demand conditions. Accordingly, the analysis was also stratified by trolley lines as well as the Coaster commuter rail line (further distinguished by downtown and other Coaster stations).

\section{DESCRIPTIVE STATISTICS}

Table 2 presents summary statistics for key variables used in the hedonic price models, disaggregated by the four land-use types. On average, commercial properties were the most expensive, followed by single-family residences, multi-family housing, and condominiums. Far higher shares of sampled commercial properties were near (i.e., within one-fourth to one-half mile of) a Trolley or Coaster station (19\%) than other uses; $10 \%$ of multi-family housing and condominiums and $5 \%$ of single-family homes were near stations.

Commercial and multi-family housing structures were generally the largest (on average, over 5,000 square feet) and condominiums the smallest (just over 1,000 square feet). Multi-family projects (many of which were duplexes) tended to be in the densest settings and, predictably, single-family 
Table 2: Descriptive Statistics of Key Variables Used in Hedonic Price Model for Residential Uses

\begin{tabular}{|c|c|c|c|c|}
\hline \multirow[b]{2}{*}{ Sales Price (measured in 2000 dollars) } & \multicolumn{4}{|c|}{ Mean or Proportion } \\
\hline & $\begin{array}{c}\text { Multi- } \\
\text { Family } \\
\text { Housing } \\
\$ 384,265\end{array}$ & $\begin{array}{l}\text { Condo- } \\
\frac{\text { miniums }^{1}}{\$ 189,396}\end{array}$ & $\begin{array}{l}\text { Single- } \\
\text { Family } \\
\text { Housing } \\
\$ 395,268\end{array}$ & $\begin{array}{c}\text { Com- } \\
\text { mercial } \\
\$ 641,321\end{array}$ \\
\hline \multicolumn{5}{|l|}{ Transportation Proximity } \\
\hline LRT (South Line): proportion within $1 / 2$ mile of station & .01 & .01 & 01 & 02 \\
\hline LRT (East Line): proportion wi hin $1 / 2$ mile of sta ion & .03 & .02 & 02 & 06 \\
\hline $\begin{array}{l}\text { LRT (Mission Valley Line): proportion wi hin } 1 / 2 \text { mile of } \\
\text { station }\end{array}$ & .02 & .04 & 01 & 03 \\
\hline LRT (Downtown): proportion within $1 / 4$ mile of sta ion & .01 & .01 & 00 & 02 \\
\hline $\begin{array}{l}\text { Commuter Rail: proportion within } 1 / 2 \text { mile of station } \\
\text { Interchange Ramp: network distance, in miles, }\end{array}$ & .03 & .02 & 01 & 06 \\
\hline to nearest freeway ramp & 137 & 1.70 & 1.91 & 1.58 \\
\hline \multicolumn{5}{|l|}{$\begin{array}{l}\text { Transportation Accessibility Measures } \\
\text { Regional Job Accessibility: Number of jol }\end{array}$} \\
\hline $\begin{array}{l}\text { in 1995) within } 30 \text { minute peak-period auto travel ime } \\
\text { on highway network }\end{array}$ & 794,374 & 761,490 & 675,287 & -- \\
\hline $\begin{array}{l}\text { Regional Household Accessibility: Number of households } \\
\text { (in 1,000s) within 30-minute peak-period travel time on } \\
\text { highway network }\end{array}$ & -- & -- & -- & 590.393 \\
\hline \multicolumn{5}{|l|}{ Property and Location Attributes } \\
\hline Structure Size (square feet) & 5,174 & 1,157 & 1,887 & 6,681 \\
\hline Lot Size (square feet) & 23,263 & $-2^{2}$ & 10,795 & 26,534 \\
\hline Structure Age (years) & 42.7 & 19.5 & 28.9 & 35.9 \\
\hline $\begin{array}{l}\text { Housing Density: Number of housing units per gross acre } \\
\text { within one mile radius of parcel } \\
\text { Moderate-High Income: Proportion of households within one }\end{array}$ & 6.0 & 38 & 3.4 & 5.0 \\
\hline $\begin{array}{l}\text { mile radius of parcel with median annual incomes of } \\
\$ 50,000 \text { or more }\end{array}$ & .34 & .54 & 56 & 37 \\
\hline City of San Diego Location: proportion & .57 & .57 & 51 & .45 \\
\hline
\end{tabular}

properties tended to be in sparser areas. Single-family parcels were generally in the highest income neighborhoods, opposite of multi-family structures. Relatively high shares of multi-family and condominium property sales were in the city of San Diego.

\section{HEDONIC PRICE MODEL RESULTS}

Model results for the four land uses, estimated using ordinary least squares (OLS), are presented in this section. Variables were included in models if hedonic price theory holds they are important components of price and signs of coefficients matched a priori expectations. In some cases, included variables were not statistically significant at the $5 \%$ probability levels, however this did not compromise the efficiency of parameter estimates because degrees of freedom were quite large. Using a fully specified model that is consistent with theory is common in hedonic price modeling even if variable estimates do not always meet a strict definition of statistical significance (Bartik, 1988). Still, efforts were made to include variables that had the highest probability values (i.e., significance levels) possible. This meant, however, that predictor variables that were used varied across models. In some instances, for example, job accessibility (as a metric of a property's location advantage) over the highway network significantly influenced property values while in other cases accessibility via highway as well as transit networks affected prices.

In addition to presenting the hedonic price associated with a property being near transit 
stations, land-value premiums or discounts are also presented in percentage terms. This involved inputting mean or modal (i.e., most frequently occurring) values into predictive models to determine price estimates for the typical property that was situated beyond $1 / 2$ mile of a rail station. Holding other factors constant, the typical price was then reestimated based on the assumption that the property lies within $1 / 2$ mile of a station. Statistically, this amounted to converting the dummy variable for a rail line of interest from a value of 0 to a value of 1 . The percentage change in estimated land value under this sensitivity analysis represented the premium, or discount, associated with being near a rail stop.

\section{Multi-Family Housing Model}

Table 3 presents the hedonic price model results for multi-family housing, which mainly consisted of apartment projects. The model has good predictive powers, explaining around 70 percent of the variation in sales prices among some 1,500 multi-family properties sold in year 2000 .

Large and positive price capitalization effects were found for apartments and other multi-family parcels near Trolley stops. The largest benefits accrued to parcels near the East Line: an apartment within 1/2 mile of an East Line Trolley stop was worth, on average, more than \$100,000 more than an otherwise comparable apartment project that was beyond walking distance to a station. For the other light-rail lines, the impact of being near a Trolley stop, while positive, was not statistically significant at the $5 \%$ probability level. Multi-family housing projects near Coaster stations generally sold at a lower price than otherwise comparable projects, suggesting the existence of a disamenity effect. Since commuter rail lines often serve professional-class, home-owning workers, the absence of a meaningful relationship for apartments and rental units seems reasonable. The model results also suggest a disbenefit from being close to freeways (e.g., from noise, fumes, vibrations, headlight glare, etc.), reflected by prices increasing by around $\$ 67,000$ for every mile a multi-family housing parcel was away from a freeway, ceteris paribus. However, being near an access point to a freeway (i.e., an on-ramp) created benefit, reflected by the negative sign on the “Interchange Ramp” variable, with prices decreasing by about $\$ 43,000$ for every mile a parcel was away from a freeway ramp, all else being equal. Overall, the disamenity effect of being near a freeway was larger than the amenity effect of being close to a freeway access point.

The other variables in the hedonic price model entered as statistical controls, to remove the influences of other explainers of multifamily housing prices. All control variables had signs that matched expectations. All else being equal, multi-family housing in San Diego County sold for more as the following increased: access to regional jobs over the highway network; structure size; numbers of units, bedrooms, and bathrooms; neighborhood income; shares of households made up of white and seniors; and amounts of vacant parcels(reflecting possible real-estate speculative effects). Multi-family housing sold for less as age of the structure and housing density in the immediate neighborhood increased. Municipality and monthly fixedeffect controls were introduced in the model, however results are not shown in the table for brevity. Prices were generally higher for multi-family parcels sold in the wealthier northern part of the county and in the later portions of year 2000 .

In summary, proximity to transit conferred a statistically significant premium only to one of the corridors - the East Trolley line. Inputting mean or modal values for all of the variables in the predictive model, the estimated premium associated with apartments lying with 1/2 mile of an East Line station was $17 \%$. Keep in mind that this premium reflects average conditions; to the degree the characteristics of a multi-family parcel differ from the county-wide average (as summarized in Table 2), then the estimated premium will itself differ. 
Land Prices

Table 3: Multi-Family Housing: Hedonic Price Model for Predicting Property Values

\begin{tabular}{|c|c|c|c|}
\hline Variable & $\begin{array}{l}\text { Coeffi- } \\
\text { cient }\end{array}$ & $\begin{array}{l}\text { Standard } \\
\text { Error }\end{array}$ & $\begin{array}{l}\text { Prob. } \\
\text { Value }\end{array}$ \\
\hline \multicolumn{4}{|l|}{ Transportation Proximity } \\
\hline LRT (South Line): Within $1 / 2$ mile of LRT station (1=yes; $0=$ no) & $60,051.6$ & $44,681.4$ & .176 \\
\hline LRT (East Line): Within $1 / 2$ mile of LRT station $(1=y e s ; 0=$ no) & $104,827.4$ & $18,646.5$ & .000 \\
\hline LRT (Mission Valley Line): Within $1 / 2$ mile of LRT station ( $1=y e s ; 0=n o$ ) & $23,103.7$ & $20,021.2$ & .320 \\
\hline LRT (Downtown): Within $1 / 4$ mile of LRT station ( $1=y e s ; 0=$ no) & $31,242.3$ & $44,578.4$ & .484 \\
\hline Commuter Rail: Within $1 / 2$ mile of Coaster station ( $1=y e s ; 0=$ no) & $-43,378.8$ & $29,992.1$ & .148 \\
\hline $\begin{array}{l}\text { Highway/Freeway Distance: Straight-line mileage to nearest grade- } \\
\text { separated highway or freeway }\end{array}$ & $66,877.4$ & $14,327.0$ & .000 \\
\hline $\begin{array}{l}\text { Interchange Ramp: Network distance, in miles, to nearest freeway } \\
\text { ramp }\end{array}$ & $-43,280.2$ & $10,577.4$ & .000 \\
\hline \multicolumn{4}{|l|}{ Accessibility } \\
\hline $\begin{array}{l}\text { Regional Job Accessibility: Number of jobs (in } 1,000 \text { s, 1995) within } 1 \\
\text { hour peak-period auto travel time on highway network }\end{array}$ & 524.1 & .157 .2 & .001 \\
\hline \multicolumn{4}{|l|}{ Property Attributes } \\
\hline Structure Size: Square feet & 1.36 & 0.61 & .026 \\
\hline Units: Total number on parcel & $28,622.4$ & $2,645.4$ & .000 \\
\hline Bathrooms: Total number on parcel & $8,781.6$ & $1,876.2$ & .000 \\
\hline Bedrooms: Total number on parcel & $4,530.4$ & $1,008.7$ & .000 \\
\hline Structure Age: Years & -508.1 & 182.3 & .005 \\
\hline \multicolumn{4}{|l|}{ Neighborhood Attributes } \\
\hline $\begin{array}{l}\text { Housing Density: Number of housing units per gross acre within one } \\
\text { mile radius of parcel } \\
\text { Moderate-High Income: Proportion of households within one mile }\end{array}$ & $-5,388.2$ & $1,835.1$ & .003 \\
\hline $\begin{array}{l}\text { radius of parcel wi h median annual incomes of } \$ 50,000 \text { or more } \\
\text { Neighborhood Profile: Proportion of households within one mile radius }\end{array}$ & $113,461.8$ & $80,833.1$ & .161 \\
\hline of parcel that are white & $391,033.5$ & $33,618.0$ & .000 \\
\hline $\begin{array}{l}\text { Seniors: Proportion of population residing within one mile radius of } \\
\text { parcel that is age } 65 \text { or more }\end{array}$ & $238,415.6$ & $153,796.0$ & .121 \\
\hline $\begin{array}{l}\text { Vacant Land: Proportion of parcels within one mile radius of parcel } \\
\text { that are vacant }\end{array}$ & $1,339,402.3$ & $173,776.2$ & .000 \\
\hline Fixed Effects (omitted for brevity) & $\star \star \star \star *$ & $\star * \star *$ & 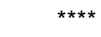 \\
\hline Constant & $-111,990.7$ & $50,859.6$ & .028 \\
\hline $\begin{array}{l}\text { Summary Statistics } \\
\text { Number of observations }=1,495 \\
\text { F Statistic (prob.) }=54.37 \quad(.000) \\
\text { R-Squared }=.695\end{array}$ & & & \\
\hline
\end{tabular}

Note: variables with prob-values $<.05$ are statistically significant at the .05 probability level.

\section{Condominiums}

Findings for condominium units are presented in Table 4. Patterns were similar to those of multi-family housing, with one notable exception: rather than there being a disamenity effect, a large and significant premium accrued to condominium parcels near Coaster stations. Apparently, the effect of being near a commuter-rail station differs depending on whether a multi-family housing property comprises for-sale or for-rent units. One can hypothesize that in the higher-income North County where many young professional workers with downtown jobs reside, owning a condo within an easy walk of a Coaster station confers benefits - on average, a valueadded of about $\$ 85,000$. Also, many of the control variables in Table 4 show similar relationships as in the case of the multi-family housing model.

For the two rail lines where proximity to transit significantly influenced condominium sales prices, the typical premiums were $6.4 \%$ for properties near East Line Trolley stations and a healthy $46 \%$ for those near Coaster stations. Although not statistically significant, premiums along other corridors were quite modest, below $4 \%$. 
Table 4: Condominiums: Hedonic Price Model for Predicting Property Values

\begin{tabular}{|c|c|c|c|}
\hline Variable & $\begin{array}{l}\text { Coeffi- } \\
\text { cient }\end{array}$ & $\begin{array}{l}\text { Standard } \\
\text { Error }\end{array}$ & $\begin{array}{l}\text { Prob. } \\
\text { Value }\end{array}$ \\
\hline \multicolumn{4}{|l|}{ Transportation Proximity } \\
\hline LRT (South Line): Wi hin $1 / 2$ mile of LRT station (1=yes; $0=n o$ ) & $6,442.5$ & $6,297.3$ & .306 \\
\hline LRT (East Line): Within $1 / 2$ mile of LRT station ( $1=y e s ; 0=n o)$ & $11,917.6$ & $4,691.9$ & .011 \\
\hline LRT (Mission Valley Line): Within $1 / 2$ mile of LRT sta ion (1=yes; $0=$ no) & $5,539.6$ & $7,373.8$ & .453 \\
\hline LRT (Downtown): Within $1 / 4$ mile of LRT station (1=yes; $0=$ no) & $4,144.8$ & $3,782.9$ & .273 \\
\hline Commuter Rail: Within $1 / 2$ mile of Coaster station (1=yes; $0=$ no) & $85,232.1$ & $6,728.7$ & .000 \\
\hline \multicolumn{4}{|l|}{ Interchange Ramp: Network distance, in miles, to nearest freeway } \\
\hline ramp & $7,655.0$ & 714.6 & .000 \\
\hline \multicolumn{4}{|l|}{ Accessibility } \\
\hline \multicolumn{4}{|l|}{ Regional Job Accessibility: Number of jobs (in 1,000s, in 1995) within } \\
\hline 30 minute peak-period auto travel time on highway network & 71.9 & 10.1 & .000 \\
\hline \multicolumn{4}{|l|}{ Property Attributes } \\
\hline Structure Size: Square feet & 217.3 & 3.2 & .000 \\
\hline Bathrooms: Total number on parcel & $-3,514.0$ & $1,927.9$ & .068 \\
\hline Bedrooms: Total number on parcel & $-15,129.1$ & $1,500.6$ & .000 \\
\hline Structure Age: Years & $-1,577.6$ & 98.7 & .000 \\
\hline \multicolumn{4}{|l|}{ Neighborhood Attributes } \\
\hline $\begin{array}{l}\text { Housing Density: Number of housing units per gross acre within one } \\
\text { mile radius of parcel }\end{array}$ & $5,731.6$ & 450.7 & .000 \\
\hline $\begin{array}{l}\text { Employment Density: Number of workers per gross acre within one } \\
\text { mile radius of parcel }\end{array}$ & $1,092.4$ & 182.3 & .000 \\
\hline $\begin{array}{l}\text { Moderate-High Income: Proportion of households within one mile } \\
\text { radius of parcel with median annual incomes of } \$ 50,000 \text { or more }\end{array}$ & $22,242.5$ & $8,215.5$ & .006 \\
\hline $\begin{array}{l}\text { White: Propor ion of households within one mile radius of parcel } \\
\text { that are white }\end{array}$ & $103,272.1$ & $5,085.0$ & .000 \\
\hline $\begin{array}{l}\text { Vacant Land: Proportion of parcels within one mile radius of parcel } \\
\text { that are vacant }\end{array}$ & $917,470.4$ & $26,625.9$ & .000 \\
\hline Fixed Effects (omitted for brevity) & $\star \star \star * *$ & $\star \star * *$ & $\star * \star *$ \\
\hline Constant & $-240,085.0$ & $10,310.9$ & .000 \\
\hline $\begin{array}{l}\text { Summary Statistics } \\
\text { Number of observations }=9,672 \\
\text { F Statistic (prob.) }=467.8(.000) \\
\text { R-Squared }=.735\end{array}$ & & & \\
\hline
\end{tabular}

Note: variables with prob-values $<.05$ are statistically significant at the .05 probability level.

\section{Single-Family Housing}

While multi-family units often benefit from being near rail transit, frequently the opposite holds for single-family housing, especially in the case of established, middle-income neighborhoods. This is the case in San Diego County. Among properties along Trolley corridors, Table 5 shows significant disamenity effects from being near stations along three of the four Trolley lines. Only in the case of the South Line, where single-family home prices tend to be lower than elsewhere in the region, were land-value premiums associated with being near transit found, albeit this relationship was not statistically significant. Interestingly, single-family homes within $1 / 2$ mile of Coaster stations reaped large and significant benefits (on average, more than
\$78,000), similar in size to the other owneroccupied housing previously examined: condominiums.

Table 5 also shows interesting relationships between single-family home prices and highways. Single-family home prices generally fell with distance to the nearest freeway, offset by the accessibility benefits of being near an interchange access point, suggesting that, overall, properties generally sold for more when they were situated a reasonable buffer distance away from busy roads. Proximity to ramps versus freeway segments was measured to distinguish benefits of being near an access point - i.e., a ramp - versus the nuisance effects of being near a major thoroughfare. Still, single-family homeowners generally do not want to be too far away from freeways as revealed by the job 
accessibility variable: homes fetched higher prices as access to jobs via automobile (within 30 minutes peak time) increased. Employment access via transit similarly increased the value of single-family homes.

Control variables from Table 5 matched hedonic price expectations. Single-family home prices generally rose: with structure size and number of bathrooms; in predominantly white neighborhoods with higher incomes; and in North County communities known for having good schools (though these premium effects are not shown in the table for brevity sake). The sign on the lot size variable was negative (though not significant at the .05 probability level), suggesting parcels that devote more land to structures than open space tend to be worth more in the marketplace. While the sign on the housing density variable is positive, suggesting homes in more builtup areas sell for more, the average density of single-family neighborhoods was still fairly low (3.4 units per gross acre, from Table 2), suggesting this is not capturing so much the effects of high density as much as salestransacted parcels being in fairly mature, builtup areas.

Expressing the hedonic price results in premium terms, the typical single-family home within a half mile of a non-downtown Coaster station reaped a premium benefit of around $17 \%$. All other impacts were small and statistically insignificant.

\section{Commercial Properties}

For commercial uses, properties that were near Mission Valley Trolley stations and the downtown Coaster station reaped large and positive land-value premiums, as revealed in Table 6. In total dollar terms, the premiums to these locations were higher than for other land uses, consistent with real estate economic theories that hold commercial properties generally bid up the accessibility benefits conferred by proximity to major transportation facilities. It is also noteworthy that transit produced appreciable benefits to properties in one of the healthiest commercial real estate markets in the region: the Mission Valley Line and, in the case of commuter services, downtown San Diego. More modest benefits accrued to offices and retail establishments near downtown Trolley stations and disbenefits were measured for properties near South Line and East Line Trolley stops (although they were not statistically significant). The largest disbenefit was found for commercial properties within $1 / 2$ mile of non-downtown Coaster stations. Also, Table 6 shows that the farther a commercial property was from a freeway interchange, the more its land value declined. The commercial hedonic price model provided a very good statistical fit, explaining 83 percent of the variation in commercial property sales prices.

Control variables from Table 6 align with expectations. Commercial properties were worth more as the number of households that could be reached within 30-minutes peak auto travel time increased. Values also rose with structure and lot sizes, although by small amounts. Holding other factors constant, the table shows that commercial properties used for offices, retail stores, restaurants, and hotels tended to have higher prices than those used for community shopping centers, grocery or drug stores, and theaters. In addition, the positive sign on the employment density variable is suggestive of agglomeration and comparison-shopping benefits (i.e., advantages conferred by spatial clustering, such as access to specialized skills, ease of face-to-face transactions, and ability to compare prices among multiple stores). Commercial values also tended to be higher in higher-income and predominantly white neighborhoods. Commercial properties near the Mexican border generally also sold for more, reflecting the benefits of being near one of the world's busiest border crossings.

In percentage terms, the price premiums for commercial properties were quite substantial in two major business settings: downtown Coaster stations (91.1\%) and the Mission Valley Line (71.9\%). The valueadded to downtown Coaster stations could reflect the benefits of offices being located 


\begin{tabular}{|c|c|c|c|}
\hline Variable & $\begin{array}{c}\text { Coeffi- } \\
\text { cient }\end{array}$ & $\begin{array}{l}\text { Standard } \\
\text { Error }\end{array}$ & $\begin{array}{l}\text { Prob. } \\
\text { Value }\end{array}$ \\
\hline \multicolumn{4}{|l|}{ Transportation Proximity } \\
\hline LRT Straightline Distance, in miles & $-5,659.3$ & 393.7 & .000 \\
\hline LRT (South Line): Within $1 / 2$ mile of LRT station ( $1=y e s ; 0=$ no) & $6,774.8$ & $21,495.6$ & .753 \\
\hline LRT (East Line): Within $1 / 2$ mile of LRT station ( $1=y e s ; 0=n o$ ) & $-17,643.0$ & $9,456.3$ & .062 \\
\hline \multicolumn{4}{|l|}{ LRT (Mission Valley Line): Within $1 / 2$ mile of LRT station (1=yes; } \\
\hline Commuter Rail Straight-line Distance, in miles & $-12,308.3$ & 537.8 & .000 \\
\hline Commuter Rail: Within $1 / 2$ mile of Coaster station ( $1=y e s ; 0=$ no) & $78,597.9$ & $29,389.6$ & .007 \\
\hline $\begin{array}{l}\text { Highway/Freeway Distance: Straight-line mileage to nearest } \\
\text { grade-separated highway or freeway }\end{array}$ & $13,295.3$ & $2,258.5$ & .000 \\
\hline $\begin{array}{l}\text { Interchange/Ramp: Network distance, in miles, to nearest } \\
\text { freeway ramp }\end{array}$ & $-8,762.5$ & $3,195.9$ & .006 \\
\hline \multicolumn{4}{|l|}{ Accessibility } \\
\hline $\begin{array}{l}\text { Regional Job Accessibility, Highway: Number of jobs (in 1,000s, } \\
\text { 1995) within } 30 \text { minute peak-period auto travel time on } \\
\text { highway network }\end{array}$ & $1,042.0$ & 160.4 & .000 \\
\hline \multicolumn{4}{|l|}{ Regional Job Accessibility, Transit: Number of jobs (in 1,000s, } \\
\hline $\begin{array}{l}\text { 1995) within } 15 \text { minute peak-period transit travel time on } \\
\text { highway network }\end{array}$ & $6,286.5$ & 710.2 & .000 \\
\hline \multicolumn{4}{|l|}{ Property Attributes } \\
\hline Structure Size: Square feet & 185.9 & 3.2 & .000 \\
\hline Lot Size: Square feet & -0.2 & 0.1 & .181 \\
\hline Bathrooms: Total number on parcel & $25,014.7$ & $3,299.4$ & .000 \\
\hline Bedrooms: Total number on parcel & $-26,745.5$ & $1,862.4$ & .000 \\
\hline Structure Age: Years & $-1,253.4$ & 433.9 & .000 \\
\hline \multicolumn{4}{|l|}{ Neighborhood Attributes } \\
\hline \multicolumn{3}{|l|}{ Housing Density: Number of housing units per gross acre within } & .000 \\
\hline $\begin{array}{l}\text { High Income: Proportion of households within one mile radius of } \\
\text { parcel with median annual incomes of } \$ 100,000 \text { or more }\end{array}$ & $360,920.5$ & $18,402.0$ & .000 \\
\hline \multicolumn{4}{|l|}{ White: Proportion of households within one mile radius of parcel } \\
\hline Fixed Effects (omitted for brevity) & $20,00.1$ & $*$ **** & 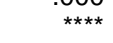 \\
\hline Constant & $-1,202.1$ & $20,523.8$ & .953 \\
\hline \multicolumn{4}{|l|}{ Summary Statistics } \\
\hline $\begin{array}{l}\text { Number of observations }=14,756 \\
\text { F Statistic (prob.) }=351.4(.000) \\
\text { R-Squared }=.605\end{array}$ & & & \\
\hline
\end{tabular}

Note: variables with prob-values $<.05$ are statistically significant at the .05 probability level.

near a commuter-rail line that serves upper income neighborhoods with professional-class workers. And the benefits of being near transit to offices, shops, and businesses in the Mission Valley corridor could reflect the synergies of pro-active TOD planning in a fast-growing area. Outside of these two settings, the only other premium was recorded near downtown Trolley stations - a far more modest $4.4 \%$ capitalization benefit that was not statistically significant. Elsewhere, disbenefits were recorded, albeit they were not statistically significant.

\section{CONCLUSION}

Rail transit services in the San Diego region have conferred land-value benefits to residential and commercial properties, though relationships vary considerably by land uses and corridors and instances of land-value discounts were found. In general, the biggest premiums accrued where theory suggests they would: for commercial properties in downtown San Diego and along the Mission Valley corridor, both settings which at the time of the analysis had healthy real estate markets 


\begin{tabular}{|c|c|c|c|}
\hline Variable & $\begin{array}{l}\text { Coeffi- } \\
\text { cient }\end{array}$ & $\begin{array}{l}\text { Standard } \\
\text { Error }\end{array}$ & $\begin{array}{l}\text { Prob. } \\
\text { Value }\end{array}$ \\
\hline \multicolumn{4}{|l|}{ Transportation Proximity } \\
\hline LRT (South Line): Wi hin $1 / 2$ mile of LRT station (1=yes; $0=n o$ ) & $-104,266.8$ & $364,845.9$ & .775 \\
\hline LRT (East Line): Within $1 / 2$ mile of LRT station ( $1=y e s ; 0=$ no) & $-12,795.6$ & $194,455.4$ & .887 \\
\hline LRT (Mission Valley Line): Within $1 \frac{1}{2}$ mile of LRT sta ion ( $1=y e s ; 0=n o$ ) & $813,124.2$ & $272,515.2$ & .003 \\
\hline LRT (Downtown): Within $1 / 4$ mile of LRT station (1=yes; $0=$ no) & $50,196.4$ & $48,659.6$ & .352 \\
\hline Commuter Rail: Within $1 / 2$ mile of Coaster station (1=yes; $0=$ no) & $-111,917.0$ & $53,977.1$ & 004 \\
\hline \multicolumn{4}{|l|}{ Commuter Rail: Wi hin $1 / 4$ mile of downtown Coaster station (1=yes; } \\
\hline $0=$ no) & $1,143,027.5$ & $539,776.1$ & .035 \\
\hline $\begin{array}{l}\text { Interchange Ramp: Network distance, in miles, to nearest freeway } \\
\text { ramp }\end{array}$ & $-39,749.2$ & $43,403.9$ & .360 \\
\hline \multicolumn{4}{|l|}{ Accessibility } \\
\hline \multicolumn{4}{|l|}{ Regional Household Accessibility: Number of households (in 1,000s) } \\
\hline within 30 -minute peak-period travel time on highway network & $1,260.1$ & 57.0 & .000 \\
\hline \multicolumn{4}{|l|}{ Property and Land Use Attributes } \\
\hline Structure Size: Square feet & 79.0 & 4.5 & 000 \\
\hline Lot Size: Square feet & 4.6 & 1.4 & 001 \\
\hline Community Shopping Center (1=yes; $0=$ no) & $-439,009.1$ & $262,213.9$ & 095 \\
\hline Grocery or Drug Store (1=yes; $0=$ no) & $-354,610.5$ & $297,241.4$ & .234 \\
\hline Restaurant (1=yes; $0=$ no) & $293,487.6$ & $118,874.3$ & .014 \\
\hline Theater $(1=y e s ; 0=$ no $)$ & $-6,968,965$ & $673,874.5$ & .000 \\
\hline Hotel or Motel $(1=y e s ; 0=$ no $)$ & 325,410 & $136,386.4$ & .018 \\
\hline Office or Store: 4 stories or more $(1=y e s ; 0=$ no) & $1,360,015.7$ & $532,562.3$ & .011 \\
\hline \multicolumn{4}{|l|}{ Neighborhood Attributes } \\
\hline \multicolumn{4}{|l|}{ Employment Density: Number of workers per gross acre within one } \\
\hline \multicolumn{3}{|l|}{ High Income: Proportion of households within one mile radius of parcel } & .000 \\
\hline \multicolumn{4}{|l|}{ White: Propor ion of households within one mile radius of parcel } \\
\hline that are white race, 2000 & $341,834.6$ & $153,574.0$ & .027 \\
\hline Mexican Border: Parcel within one mile radius of Mexican border & $774,284.2$ & $404,153.6$ & .056 \\
\hline Fixed Effects (omitted for brevity) & 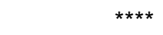 & 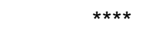 & 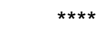 \\
\hline Constant & $-1,312,708.0$ & $401,028.6$ & .001 \\
\hline \multicolumn{4}{|l|}{ Summary Statistics } \\
\hline \multicolumn{4}{|l|}{$\begin{array}{l}\text { Number of observations }=372 \\
F \text { Statistic (prob })=40.24(000)\end{array}$} \\
\hline F Statistic $($ prob.) $=40.24(.000)$ & & & \\
\hline R-Squared $=.830$ & & & \\
\hline
\end{tabular}

Note: variables with prob-values $<.05$ are statistically significant at the .05 probability level.

and for which profit-seeking businesses could be expected to bid up the price for parcels strategically well-situated with reference to transit. However, the largest price discount effects also appeared for commercial uses, although these were generally not statistically significant and occurred in more tepid real estate sub-markets.

For residential properties, market dynamics varied by type and corridor. Multifamily parcels reaped significant positive benefits only in the case of the East Trolley Line, a moderate-income working-class corridor. Condominiums enjoyed premiums along all corridors, with the largest (and only statistically significant) benefit accruing to properties near commuter rail stations, perhaps reflecting the appeal of being near high-speed, downtown-serving transit among the many professional-class workers who reside in the northern part of the county. For single-family housing, significant benefits similarly accrued to properties near Coaster stations; elsewhere, however, impacts were either insignificant or, in the case of two of the Trolley corridors, negative.

While this research did not prove that rail investments cause land-value changes (given that before-and-after data were not used), the hedonic price results suggest a reasonably 
strong association between proximity to transit and land values. The benefits of being near transit are not automatic, however, even in places like San Diego County where TOD and smart-growth planning have been aggressively pursued. Where market conditions are conducive and pro-development policies are in place, this research suggests land-value impacts can be substantial. Notably, the highest land-value benefits conferred to offices, retail establishments and other commercial uses occurred in the Mission Valley and near downtown stations. Both settings have been the beneficiaries of proactive TOD planning, including targeted public infrastructure and streetscape improvements and the introduction of overlay zones that encourage mixed uses. In addition to pro-active planning, localized factors, like the relative softness of real estate markets as well as socio-economic characteristics, also probably explain varied experiences in these and other situations. The varying nature of accessibility benefits that accrue among different land uses and forms of rail transit could also account for differences. This research also suggests that accessibility benefits conferred by commuter rail (i.e., relatively fast connectivity to downtown districts during peak hours) seem to be greatest in high-income districts populated by professional-class workers, similar to what has been found in Santa Clara County (Cervero and Duncan, 2002). Moreover, the empirical results suggests that in the case of apartments and other multi-unit complexes, light-rail's largest premiums accrue in working class and moderate-income settings.

Compared to the results of studies conducted a decade or more ago, the presentday land-value impacts of light-rail and commuter-rail services in San Diego County are fairly appreciable. This could reflect a combination of factors - a fairly robust local economy, a more mature light-rail system, a large and diverse network of fixed-guideway transit services, and the cumulative impacts of pro-TOD policies of the past decade. Longitudinal studies of capitalization effects carried out over longer time frames offer the best hope of sorting out these influences.

Recent research suggests capitalization effects can contribute to transit oriented development. Knapp et al. (2001) found that capitalization in Portland, Ore., increased housing densities near a number of light-rail stations. To the degree that TOD and capitalization are mutually reinforcing, local transit and planning agencies stand to gain, in terms of not only revenue (e.g., through higher property tax proceeds and the lease of air rights) but also ridership increases. The moderately strong relationships found in this research, reflected by substantial differences in capitalization effects among land uses, modes, and corridors, suggest that public policies and decisions have important roles to play in shaping land-use and land-price outcomes. 


\section{References}

Al-Moisand, M., K. Dueker, and J. Strathman. "Light-Rail Transit Stations and Property Values: A Hedonic Price Approach.” Transportation Research Record 1400 (1993): 90-94.

Alonso, W. Location and Land Use. Harvard University Press, Cambridge, MA, 1964.

American Public Transit Association. Transit Fact Book., Washington, D.C., 2002.

Bartik, T. "Measuring the Benefits of Amenity Improvements on Hedonic Models.” Land Economics 64, 2 (1988): 172-183.

Bernick, M. and R. Cervero. Transit Villages for the 21 ${ }^{\text {st }}$ Century, New York, McGraw-Hill, 1997.

Boarnet, M. and R. Crane. Travel by Design: The Influence of Urban Form on Travel. New York, Oxford University Press, 2001.

Bollinger, C., K. Ihlanfeldt, and D. Bowes. "Spatial Variation in Office Rents Within the Atlanta Region.” Urban Studies 35, 7 (1998): 1097-1117.

Calthorpe, P. The Next American Metropolis: Ecology, Community and the American Dream. New York, Princeton Architectural Press, 1993.

Cervero, R. "Rail Transit and Joint Development.” Journal of the American Planning Association 60, 1 (1994): 83-94.

Cervero, R. Transit-Induced Accessibility and Agglomeration Benefits: A Land Market Evaluation. Berkeley, Institute of Urban and Regional Development, University of California, Berkeley, Working Paper 691, 1997.

Cervero, R. and M. Duncan. “Rail’s Added Value.” Urban Land 61, 2 (2002): 77-84.

Falcke, C. Study of BART's Effects on Property Prices and Rents. Washington, D.C., Urban Mass Transportation Administration, U.S. Department of Transportation, 1978.

Gatzlaff, D. and M. Smith. "The Impact of the Miami Metrorail on the Value of Residences Near Station Locations.” Land Economics 69, 1 (1993): 54-66.

Graham, W. Land Use Effects of Light Rail Transit: The San Diego Example. San Diego, Department of City Planning, San Diego State University, unpublished Masters Thesis, 1992.

Great American Station Foundation. Economic Impact of Station Revitalization, Las Vegas, New Mexico, 2001.

Knapp, G., C. Ding and L. Hopkins. "Do Plans Matter? The Effects of Light Rail Plans on Land Values in Station Areas.” Journal of Planning Education and Research, 21 (2001): 32-39.

Koenig, J. “Indicators of Urban Accessibility: Theory and Applications.” Transportation 9 (1980): 145-172.

Landis, J., S. Guathakurta, and M. Zhang. Capitalization of Transportation Investments into SingleFamily Home Prices. Berkeley, Institute of Urban and Regional Development, University of California, Working Paper 619, 1994.

Landis, J. and D. Loutzenheiser. BART at 20: BART Access and Office Building Performance. Berkeley, Institute of Urban and Regional Development, University of California, 1995. 
Lin, J. "Gentrification and Transit in Northwest Chicago.” Journal of the Transportation Research Forum 56, 4 (2002): 175-191.

Nelson, A. "Effects of Elevated Heavy-Rail Transit Stations on House Prices with Respect to Neighborhood Income.” Transportation Research Record 1359 (1992): 127-132.

Nelson, A. "Transit Stations and Commercial Property Values: A Case Study with Policy and LandUse Implications.” Journal of Public Transportation 2, 3 (1992): 77-93.

Rosen, S. "Hedonic Prices and Implicit Markets: Product Differentiation in Pure Competition." Journal of Political Economics 82 (1974): 601-630.

San Diego Association of Governments. San Diego Trolley: The First Three Years. Washington, D.C., Urban Mass Transportation Administration, U.S. Department of Transportation, 1984.

Texas Transportation Institute. 2002 Annual Urban Mobility Report. College Park, Texas Transportation Institute, Texas A\&M University, 2002.

VNI Rainbow Appraisal Service. Analysis of the Impact of Light Rail Transit on Real Estate Values. San Diego, Metropolitan Transit Development Board, 1992.

Voith, R. "Changing Capitalization of CBD-Oriented Transportation Systems: Evidence from Philadelphia, 1970-1988.” Journal of Urban Economics 33 (1993): 361-376.

Weinstein, B. and T. Clower. The Initial Economic Impacts of the DART LRT System. Denton, University of North Texas, Center for Economic Development and Research,1999.

Weinberger, R. "Light Rail Proximity: Benefit or Detriment in the Case of Santa Clara County, California?” Transportation Research Record 1747 (2001): 104-111.

Workman, S. and Brod, D. "Measuring the Neighborhood Benefits of Rail Transit Accessibility." Transportation Research Record 1576 (1997): 147-153.

\section{Acknowledgement}

This work was supported by grants provided by the National Association of Realtors, the Urban Land Institute, and San Diego's Metropolitan Transit Development Board. Michael Duncan provided valuable assistance with building the data base used in conducting this research.

Robert Cervero is professor of city and regional planning at the University of California at Berkeley. His recent research has been on the benefits of transit-oriented development and carsharing in the United States. He is the author of "The Transit Metropolis, Paratransit in America, Informal Transport in the Developing World, Transit Villages for the 21st Century, America's Suburban Centers, and Suburban Gridlock." 